\title{
Does Teaching Practice Effectively Prepare Student-Teachers to Teach Creative and Performing Arts? The Case of Botswana
}

\author{
Dr. Magdeline C. Mannathoko \\ ${ }^{1}$ Faculty of Education - Primary Education Department, University of Botswana, Botswana \\ Correspondence: Dr. Magdeline C. Mannathoko, Faculty of Education - Primary Education Department, University \\ of Botswana, Botswana. E-mail: mannathoko@mopipi.ub.bw \\ Received: February 11, 2013 \\ Accepted: April 26, 2013 \\ Online Published: May, 2013 \\ doi:10.5430/ijhe.v2n2p115 \\ URL: http://dx.doi.org/10.5430/ijhe.v2n2p115
}

\begin{abstract}
Teacher Education involves the policies and procedures designed to equip teachers with the knowledge and skills they require to teach effectively. Teaching practice (TP) is an integral part in teacher education because it allows student-teachers to apply the theories into practice. Effective preparation of student-teachers in practical subjects could help them teach the arts efficiently. As a result, promoting learners' skills specifically; creative and practical skills support healthy development. This qualitative study explored the extent to which teaching practice in primary Colleges of Education prepared student-teachers to teach Creative and Performing Arts (CAPA) subjects in primary schools. The study was conducted in three Colleges of Education located in the South East, Central and Francistown districts of Botswana. The participants were third year student-teachers and students who completed in colleges six to two years ago. The findings revealed that student-teachers in the three Colleges of Education were introduced to the general pedagogy skills of teaching in primary schools by their tutors who in most cases were not arts specialists. There were concerns from student-teachers that lecturers rarely assessed the arts during teaching practice and therefore, trainees did not get any assistance to prepare them to teach the CAPA subjects.
\end{abstract}

Keywords: Teaching practice, Creative and performing arts, Preparation; Supervision, Student-teachers, Tutors, Tutorials, Assessment

\section{Introduction}

Creative and Performing Arts in Botswana is at its infancy stage. The program was introduced in primary schools in 2002 and like all subjects at that level; it was made compulsory for all students. It comprises of four disciplines (art and craft, design and technology, music and physical education) at lower primary and six disciplines (art and craft, design and technology, music, physical education, home economics and business studies) at upper primary. The curriculum was a response to the requirement of the Revised National Policy on Education (RNPE, 1994) which recommended that "a wide range of practical subjects be included in the primary curriculum in order to help students develop an understanding and appreciation of technology, manipulative skills and familiarity with tools, equipment and materials" (Curriculum Development and Evaluation Division, 2002, p. 1). Most primary school teachers in Botswana have limited knowledge and skills in Creative and Performing arts (CAPA) disciplines (Phibion, 2006, Phuthego, 2006 and Mannathoko, 2009) therefore, those who get opportunities to go for further training need effective training in this area; through application of methodologies during classroom lectures, tutorials and assistance during teaching practice for them to successfully implement the CAPA syllabus when returning to the teaching field. Thus, teaching practice (TP) is perceived by educators as a training requirement for teachers.

Teacher training institutions engage student-teachers in teaching practice because they view it as an important part of teacher education. This is the time student-teachers are given the opportunity to practice the techniques of teaching to prepare them for the real world of the teaching profession. Student-teachers also know the rationale for teaching practice; they view it as an important aspect of their preparation for the teaching profession since it provides them with the skills of the real teaching profession. The supervisor should conference with the students before and after the class observation (Major and Mannathoko, 2013). However, despite its importance, teaching practice could be very challenging and hence demoralizing and sometimes very frightening experience if students are not well prepared. It is worth noting that students' experiences during teaching practice can influence their perception and attitudes towards the teaching of the subjects they are trained to teach and their teaching profession as a whole. 
It is in this context that, I investigated the extent to which teaching practice in Colleges of Education (Primary) prepared student-teachers to teach Creative and Performing Arts (CAPA) disciplines. Perry (2004) explains that teaching practice can be conducted in different forms depending on the institution. In Botswana Colleges of Education, it is in three phases. In their first year of study, students go for two weeks of observation and on completion compile reports which are graded by their tutors. "The other two are taken during their second and third years of study respectively" (Tlokweng College of Education teaching practice handbook, 2011, p. 3). The handbook further indicates that second years have ten weeks of teaching practice while third years' teaching practice runs for five weeks. Student-teachers observe their class-teachers before taking full control of the classes.

\subsection{Purpose of the Study}

The purpose of this study was to investigate the extent to which teaching practice in Colleges of Education (primary) prepared student-teachers to teach Creative and Performing Arts subject in primary schools.

\subsection{Research Questions}

The following research questions were derived from the purpose of the study:

- To what extent are student-teachers prepared to teach CAPA during classroom lectures and tutorials before teaching practice?

- To what extent are student-teachers assisted to teach CAPA during teaching practice?

\section{Literature Review}

Several studies have been conducted on student-teachers' performance and their attitudes in teaching practice internationally, and a few research on how professional primary school teachers teach and assess the Creative and Performing Arts disciplines in Botswana. The results indicate that teachers have difficulties in teaching and assessing these disciplines and hence the study was taken to investigate the extent to which teachers were prepared during their training, with special focus on teaching practice aspect. The review of the literature indicates that there are no studies that have been conducted regarding the effectiveness of teaching practice in preparing student-teachers to implement Creative and Performing Arts curriculum in Botswana therefore, literature is been limited to the general experiences in teaching practice.

First, we need to understand what teaching practice involves and its purpose in the teacher training process. Marais and Meier (2004, p. 221) note that "the term teaching practice represents the range of experiences to which student teachers are exposed when they work in classrooms and schools." It is an integral component of teacher training and refers to students' placements to schools to practice lesson planning, classroom organization and most importantly classroom teaching. It is an essential part of effective professional training. Kiggundu and Nayimuli (2009) view it as “... a form of work-integrated learning that is described as a period of time when students are working in the relevant industry to receive specific in-service training in order to apply theory in practice" (p. 347). Thus, it is time spent by student-teachers in schools to gain practical teaching experience. The Tlokweng College of Education teaching practice handbook (2011) defines teaching practice as "the practicum, field experience or internship" (p. 5).

Different authors have shared their experiences on the rationale of teaching practice. According to www.btc.uob.edu.bh/Academic (Retrieved 6, February, 2013) the purpose of teaching practice is to prepare student-teachers for their careers as teachers by incorporating them completely into the school atmosphere so that they feel as if they are part of the school to think and meditate on the practical reality of teaching. It also pushes to encourage student-teachers to be creative and to develop their abilities as a professional teacher.

Sharing the same sentiment, Ngidi and Sibaya (2003) and Marais and Meier (2004) explain that teaching practice grants student-teachers experience in the actual teaching and learning environment therefore, it is an important component of becoming a teacher.

In addition, the University of Botswana which is the Colleges of Education affiliate, has the Faculty of Education Teaching Practice for Post Graduate Diploma in Education (PGDE) students annually and its handbook stipulates the rationale for teaching practice which tally with those of the colleges of Education. These include: enhancing student-teachers' career potentials and breadth of experiences, clarifying and inter-relating important areas of knowledge in the practical context of developing and nurturing work-related skills, fostering collaboration of all stakeholders in a way that contributes towards the quality teacher preparation, bringing together different supervisors and their varied skills to facilitate the provision of high quality supervision and mentoring and enabling studentteachers to critically examine both educational theory and practice within the appropriate contemporary educational framework of Botswana and equipping student-teachers with sufficient knowledge and skills so as to enable them to 
meaningfully extend their professional role to education and human resource development in Botswana (University of Botswana Faculty of Education handbook, 2011).

Perry (2004, p. 4) shares his experience on TP that, "although student-teachers gain specialized knowledge from class lectures, teaching practice adds value to this knowledge when students come into contact with the real classroom situation. He believes that it is during teaching practice that knowledge is affirmed. Of the same view, the University of Botswana Faculty of Education handbook (2011) contends that teaching practice forms an essential component of all the teacher education programs offered in the faculty. Thus, teachers' preparation in Colleges of Education needs to be of quality in all the subjects they are trained for, in order for them to provide quality Education to learners. It is during teaching practice that student-teachers should practice what they learnt in classrooms to prepare for their teaching profession. As aforementioned, student-teachers also perceive teaching as their preparation for the teaching profession and "as a result, teaching practice creates a mixture of anticipation, anxiety, excitement and apprehension in the student teachers as they commence their teaching practice" (Manion, Keith, Morrison and Cohen, 2003 and Perry, 2004, cited in Kiggundu and Nayimuli, 2009, p. 345). However, it can frustrate students if they are not well prepared to handle subjects they are expected to teach. These challenges, if not addressed, may affect student-teachers' performance during teaching practice and may in the long run affect their perception of the teaching profession (Quick \& Sieborger, 2005).

\section{Research Methodology}

The approach used was a qualitative case study. This method was adopted because "it allows the researcher to interact with the subject of the research and therefore, enables the researcher to focus on complexities and qualities in educational action and interaction that might be difficult to attain through the use of standardized measures" (Mannathoko, 2009, p. 101). Yin (2003) recommends qualitative studies with the view that smaller but focused samples are engaged in the study rather than large samples, to acquire thick descriptive data. Semi-structured interviews with case studies student-teachers and practicing teachers were used to collect data. In addition, government education documents and policies were examined and analyzed in relation to teaching practice procedures. Semi-structured interview method was most suitable for this type of study because it allowed participants' perception of issues in the teaching and learning of CAPA disciplines (Burns, 2000, and Creswell, 2003). It further helped me gain an in-depth understanding of the situation and meaning for those involved as I had the opportunity to probe more deeply in order to obtain in-depth information. The study was conducted in three Colleges of Education institutions located in the South East, Central and Francistown districts of Botswana. It involved fifteen third year student-teachers and ten teachers who completed in colleges of education six months to the past two years. Purposive sampling was used to identify the eligible participants. The interviews were recorded and the data transcribed.

\section{Findings and Discussions}

This section first presents the biographic data of respondents. Twenty-five participants, sixteen females and nine males took part in the study and all of them were in-service student-teachers ranging from six months to twenty-eight years of teaching experience. Among the twenty-five respondents, three specialized in religious education and social studies, four in music and agriculture, three in Languages (Setswana \& English), five in physical education and art and craft, three in art and craft and music, four in Mathematics \& Science and the last three in agriculture and home economics. Thirteen of these respondents were class-teachers without any other post of responsibility other than teaching, eight were senior teachers and the remaining four were Heads of Departments. Among the CAPA disciplines, no one was a specialist in business studies, design and technology, drama and dance as they were not offered in Colleges of Education (primary) during their training. However, student-teachers explained that some components of dance and drama were infused in music discipline through specific objectives therefore; they also taught them as such, rather than independently. The rest of the findings have been presented and discussed under the themes derived from the two research questions.

\subsection{Student-Teachers' Preparedness to Teach CAPA during Classroom Lectures and Tutorials before Teaching Practice}

It is evident through the results that not much was done by CAPA subject lecturers and students' tutors to prepare students to teach CAPA disciplines in primary schools before teaching practice. When asked how they were prepared for the process, six (24\%) revealed that they were exposed to the pedagogy in some of the CAPA disciplines mostly on how to plan lessons. The rest (76\%) indicated that they were never exposed to the methodological part, either by their CAPA lecturers or tutors and hence they were not prepared in CAPA for teaching practice. The six who revealed that they were trained how to handle CAPA explained how they were assisted by their individual lecturers 
and tutors. The assistance they got included: introduction to a sample on how to prepare for physical education and art and craft lessons during tutorial gatherings, lessons on how to plan, handle and integrate art and craft with other subjects, how to include learners with physical disabilities in physical education lessons, tutors asking them to prepare art and craft and physical education lessons including teaching aids, presenting lessons to their peers in turns and tutors supplying them with materials. According to the Tlokweng College of Education teaching practice handbook (2011) student-teachers "are expected to start their preparation in the college to get assistance from tutors" (p. 3). However, tutors in Colleges of Education are not experts in all the courses. They might have been encountering problems in tutoring students in CAPA content, activities and methodologies. One would expect individual lecturers in their respective areas of expertise to provide students with pedagogy in all the courses or topics taught in class because "the general aim of TP is to introduce prospective teachers to teaching and its routines under the guidance of a qualified professional within a broader framework of developing the skills, attitudes and competencies in the profession" (Koosimile, Monyatsi, Ngwako and Chakalisa, 2002, p. 4).

CAPA is one of the subjects in primary schools which were introduced to help children develop their practical skills, creativity, aesthetic skills and the love for the arts and hence promote self-reliance which is advocated for by the government documents such as "Vision 2016" (Curriculum Development and Evaluation Department, 2002). Its introduction came as a result of the National Commission on Education (1977) which observed that there was lack of orientation of primary education to the world of work. An omission of preparing learners including student-teachers for the world of work has been a serious debate in Botswana with some of the citizens arguing that students in high institutions were not exposed to the practical aspect of education which led to their failure in industries. Winch and Gingell (1999) cited in Major and Tiro (2012 has the same sentiment that "educators should enable students to engage fully in the world and find a place there through the pursuit of their own projects which would in most cases involve gaining employment." (p. 186). It is in this context that I argue for quality preparation of student-teachers in both classroom set up and during teaching practice, in order for them to be able to implement the CAPA syllabus, and hence enabling them to help children attain the attainment targets stipulated in the CAPA syllabus. As aforementioned, studies done by the University of Botswana lecturers Dr. Phibion (2006), Dr Phuthego (2007) and Dr Mannathoko (2009) including the Botswana Curriculum Development and Evaluation reports conducted in 2004 and 2005 indicate that primary school teachers encountered difficulties in teaching and assessing CAPA disciplines due to limited knowledge and skills in this area.

Teaching practice therefore, should be planned in a way that it serves its purpose. It was introduced to help students practice what they have learnt in classrooms, to prepare them for their teaching profession. According to the Tlokweng College of Education teaching practice handbook $(2011$, p. 6) "the primary aim of teaching practice is to assist the student teacher to develop competencies, personal characteristics, understanding, knowledge and skills needed by a professional teacher. ... It is meant to provide the student teacher with the opportunity to acquire skills and strategies or techniques to enhance his/her teaching competence."

Student-teachers therefore, should be given extensive preparation on the pedagogy aspect for each specific subject before engaging in TP. Thus, assessment on teaching practice will be based on what students learnt in classes and tutorials for quality development and hence their learners will benefit when they go back to the real teaching profession.

\subsection{Supervisors' Assistance to Student-Teachers in CAPA teaching during Teaching Practice}

Before asking students how many times they were assessed during teaching practice, I first wanted to find out how many times the case study student-teachers and practicing teachers taught CAPA during teaching practice. The responses showed that two (8\%) students taught CAPA disciplines through integration approach for 2-3 hours per week. Seventeen (68\%) respondents explained that they taught different CAPA disciplines in different days for 1-8 times a week. However, among these seventeen participants nine (24\%) emphasized that they focused only on the subjects they were specializing on. All the participants shared the same sentiment of not teaching business studies discipline as they did not understand what was required. One student emotionally said, 'I don't know those things and I don't bother myself teaching what I don't know'. The remaining six (24\%) indicated that they did not teach CAPA subject during teaching practice since they lacked knowledge and skills in most of those disciplines and tutors never showed interest in assessing those disciplines. One added that not showing interest in CAPA by those who supervised her was an opportunity for her since she was going to score low grade in that area. The six respondents who did not teach CAPA said they prepared all other subjects apart from CAPA because they were comfortable with them and that is why they succeeded in their teaching practice. 
In terms of assessment, the results showing the extent to which students were assessed in CAPA subject during TP is shown in the table below:

Table 1. CAPA Assessment per a week during teaching practice

\begin{tabular}{|c|c|c|c|c|c|}
\hline & \multirow[t]{2}{*}{ SUBJECT } & \multicolumn{4}{|c|}{ RESPONSES } \\
\hline & & s Assessed & $\begin{array}{l}\text { How many } \\
\text { Times? }\end{array}$ & $\begin{array}{l}\text { Students not } \\
\text { assessed }\end{array}$ & $\begin{array}{l}\text { Total no. } \\
\text { of respondents }\end{array}$ \\
\hline 1. & Art \& Craft & 7 & $2-3$ times & 10 & 17 \\
\hline 2. & Music & 4 & 1 time & 13 & 17 \\
\hline 3. & Design \& Technology & 1 & 2 times & 16 & 17 \\
\hline 4. & Physical education & 5 & 2-3 times & 12 & 17 \\
\hline 5. & Home Economics & 3 & 2-6 times & 14 & 17 \\
\hline 6. & Business Studies & Nil & Nil & Nil & Nil \\
\hline 7. & Integrated arts (CAPA) & Nil & Nil & 2 & 2 \\
\hline
\end{tabular}

According to those seventeen respondents who said they taught CAPA disciplines separately without integrating them, seven (41\%) confirmed that they were assessed in art and craft 2-3 times during teaching practice whereas, ten $(59 \%)$ mentioned that they were never assessed in that area; four (24\%) were assessed in music once, $13(76 \%)$ were not; one $(6 \%)$ in design and technology twice and sixteen (94\%) were not; five (29\%) in physical education 2-3 times and twelve (71\%) were not; three (18\%) were assessed in home economics whereas, fourteen (82\%) were not. The results in the table further show that the case study student-teachers did not teach business studies as aforementioned, therefore, no assessment was done in that area and lastly, although two students taught through integration of all the arts in the CAPA syllabus, they were never assessed in that area. More assessment was done in art and craft than its core disciplines followed by physical education and the least assessment duration was in design and technology.

Still under assessment, I tried to find out from the students who were assessed, the kind of feedback they received from their supervisors. The results reveal that among the nineteen students who taught CAPA during teaching practice, nine (47\%) were assessed while ten $(53 \%)$ were not. Some of the students were assessed in more than one discipline while some were not assessed at all. Among the nine (47\%) students who said they were assessed teaching some of the CAPA disciplines, four $(45 \%)$ mentioned that they received positive feedback from their supervisors whereby, three of them explained that they were advised on how they should have conducted some activities during practical lessons to the extent of some tutors giving demonstrations while some provided materials for the lessons. One of these four participants said he was not assisted because she presented her lesson well. Two ( $22 \%$ ) were concerned that some of the supervisors chose to criticize them rather than assisting them despite them having difficulties in some if not all the CAPA disciplines. One of the three (33\%) students who did not get feedback after assessment was so emotional saying that when they sought help, some of their supervisors told them to find their own way of solving problems without giving any assistance. "They rely on class-teachers to help us although they are aware that these teachers have more difficulties in CAPA than student-teachers; these teachers never teach CAPA when we observe them teaching, before we take over classes; they have hopes that they will learn CAPA from us too." (She lamented, emotionally).

It is unfortunate that most of the students could not get assistance from their tutors, supervisors and class-teachers who were supposed to be their mentors although the primary aim of TP experience according to http://www.nmmu.ac.za/spte (Retrieved 6 February 2013) is to provide opportunities for student teachers to integrate theory and practice and work collaboratively with and learn from the teachers. Student teachers observe subject teachers at work so as to learn about teachers' skills, strategies and classroom achievements. They also evaluate their own teaching experiences through conferencing with teachers and lecturers and, through self-reflection, implement a variety of approaches, strategies and skills with a view to bring about meaningful learning. In this way student teachers gain experience in managing and evaluating class work; in maintaining discipline and good order in the classroom; find their own teaching style and personality and become acquainted with school organization and administration.

Thus, Ryan and Copper, (2007) believe that the entire purpose of teaching is to make positive change in students. The ten (53\%) students who taught CAPA but were not assessed were concerned that supervisors avoided CAPA lessons giving various reasons. Extracts for their responses included the following: lecturers did not have time and dedication for CAPA subject, they did not have knowledge and skills in the CAPA area therefore, were hiding by telling us to find our own way, supervisors were negligent. They were very bitter about this issue of not being helped that, they had difficulties in most of these subjects therefore, needed help. According to Oluwatayo and Adebule 
(2012, p. 110) "...the knowledge of subject matter is a critical factor at every point in the teaching process: in planning, assessing and diagnosing, task setting, questioning, explaining and giving feedback." This therefore, calls for supervisors to conference with the student-teachers before and after the class observation, for development of their teaching profession (Major and Mannathoko, 2013). CAPA is an area which primary school teachers in Botswana have problems with as most of them were not trained in some if not all CAPA disciplines. There are very few specialists in all of these disciplines and there is no one who specialized in all of them. Moreover, design and technology and business studies are not offered in Colleges of Education (primary). This calls for these colleges to revisit their tutorial system to engage specialists in all the areas of training including the pedagogy aspect. All the primary College of Education handbooks stipulate that "The success of any teacher training programme is dependent on its practical component. It is therefore necessary that the planning and supervision of teaching practice are viewed as very important tasks. It is also necessary that TP preparation as well as supervision is preceded by careful planning and organization" (Tlokweng College of Education teaching practice handbook, 2011, p. 3).

Considering the participants' concerns, they were asked to come up with suggestions on what they think could be done to improve the preparation of student-teachers to enable them to teach CAPA and the responses included the following:

- Skilled lecturers in CAPA should be hired or lecturers should be given skills in CAPA.

- Students should be taught methodologies in CAPA and demonstrations should be done to help students.

- Specialization in CAPA should be introduced in primary schools for teachers to teach subjects they are competent/comfortable with.

- CAPA subjects should have separate syllabus.

- Students should be informed about unavailable materials before engaging in TP so as to search for them.

- More practical work should be given to student-teachers.

- Syllabus content should be increased at Colleges of Education institutions for students to be more equipped with CAPA knowledge and skills.

- Student-teachers should be given extensive orientation/workshop on how to teach CAPA and be given CAPA materials to teach.

- All student- teachers should be trained in CAPA subjects and these subjects need to be valued like other subjects.

\section{Conclusions and Recommendations}

I established that, despite clear aims of teaching practice designed by Colleges of Education and included in the handbook to guide both lecturers and student-teachers, there was insufficient preparation of student-teachers to develop them as quality professionals in the CAPA area. The results revealed that not enough was done in CAPA especially the pedagogy aspect as the majority of students shared the same sentiment that there was limited assistance or no assistance at all from their tutors and supervisors before and during teaching practice despite their plea for help. Based on the findings of this study, suggestions are made on how teaching practice could be improved to effectively prepare student-teachers to teach CAPA subjects during teaching practice and hence develop positive influence on the student-teachers' perception of, and attitude towards the teaching of these subject areas. They are as follows:

- Teaching methods should be incorporated in the teaching of CAPA lessons and demonstrations made where necessary.

- Subject specialization in primary schools should be considered for students to get relevant tutorials from specialized tutors for specific subjects.

- Teaching practice coordinators should design schedules which stipulate that each subject should be assessed by a specialist in that area and demand reports from supervisors and students on findings and feedback in each lesson assessed.

- Student-teachers should be given extensive orientation/workshop by CAPA educationists on how to teach CAPA or any other subject area before teaching practice.

\section{References}

Botswana, Republic of. (1994). Revised national policy on education. Gaborone: Government Printer.

Botswana, Republic of. (1997). National commission on education. Gaborone: Government Printer. 
Burns, R.B. (2000). Introduction To research methods. London: Sage Publications Ltd.

Creswell, J.W. (Ed.) (2003). Research design, qualitative, quantitative, and mixed methods approaches. London: Sage Publications, Inc.

Curriculum Development and Evaluation Department. (2002). Lower primary school syllabus, standard one to four. Gaborone: Ministry of Education.

Curriculum Development and Evaluation Department. (2004). Standard three formative evaluation report. Gaborone: Ministry of Education.

Curriculum Development and Evaluation Department. (2005). Standard four and five formative evaluation report. Gaborone: Ministry of Education.

Curriculum Development and Evaluation Department. (2005). Upper primary school syllabus, standard one to four. Gaborone: Ministry of Education.

http://www.btc.uob.edu.bh/Academic (Retrieved 6 February, 2013).

http://www.nmmu.ac.za/spte (retrieved 6 February 2013).

Kiggundu, E., \& Nayimuli, S. (2009). Teaching practice: A make or break phase for student teachers. South African Journal of Education, 29(3), 345-358.

Koosimile, A., Monyatsi, P.P., Ngwako, A.D., \& Chakalisa, P.A. (2002). Teaching practice handbook: Notes of guidance for student teachers, supervisors and examiners. Gaborone: University of Botswana.

Major, T., \& Tiro, L. (2012). Theory Vs. Practice: The Case of primary teacher education in Botswana. International Journal of Scientific Research in Education, 5(1), 63-70.

Major, T.E., \& Mannathoko, M.C. (2013). Listening to the voices of the post graduate diploma in education (Preservice) student teachers in Botswana. International Journal of Scientific Research and Application, 1(2), $38-46$.

Mannathoko. M.C. (2009). Interpreting the new lower primary art and craft component of the Creative and Performing Arts, the Botswana National Curriculum. Case studies of four primary schools in the South Central and Central North Regions. Doctoral dissertation, Cardiff University of Wales Institute, Cardiff. [Online] Available:

http://repository.uwic.ac.uk/dspace/bitstream/10369/845/1/MC\%20Mannathoko\%20Art\%20and\%20Design\%20 Phd\%20Thesis\%20June\%2009.\%20doc.pdf

Marais P., \& Meier C. (2004). Hear our voices: Student teacher's experience during practical teaching. Africa Education Review, 1, 220-233. http://dx.doi.org/10.1080/18146620408566281

Oluwatayo, J.A., \& Adebule, S. O. (2012). Assessment of teaching performance of student-teachers on teaching practice. International Education Studies, 5(5), 110. http://dx.doi.org/10.5539/ies.v5n5p109

Perry, R, (2004). Teaching Practice for Early Childhood. A guide for students. [Online] Available: http://www Routledge.com catalogues./0418114838.pdf. on Retrieved 13 June 2012.

Phibion, O, S. (2006). Botswana Primary school teachers' perception on the introduction of the Creative and Performing Arts (CAPA) A case of Lobatse town (Urban) and Tlokweng Village (Semi-Urban) schools. Gaborone: University of Botswana.

Phuthego, M. (2007). An evaluation of the indigenous musical arts in the creative and performing arts syllabus and the implementation thereof in the primary schools curriculum in Botswana. Unpublished Music Thesis. Pretoria: University of Pretoria.

Quick, G., \& Sieborger, R. (2005). What matters in practice teaching? The perception of schools and students. South African Journal of Education, 25, 1-4.

Ryan, K., \& Cooper, J. M. (2007). Kaleidoscope readings in education (11th ed.) New York: Houghton Mifflin Company.

Teaching Practice Department. (2011). Teaching practice handbook. Tlokweng: Tlokweng College of Education.

University of Botswana, Faculty of Education. (2011). Teaching practice/internship handbook 2011/2012. Gaborone: University of Botswana.

Yin, R. K. (ed.) (2003). Case study research, design and methods: Applied social research methods series. London: Sage Publications Inc. 